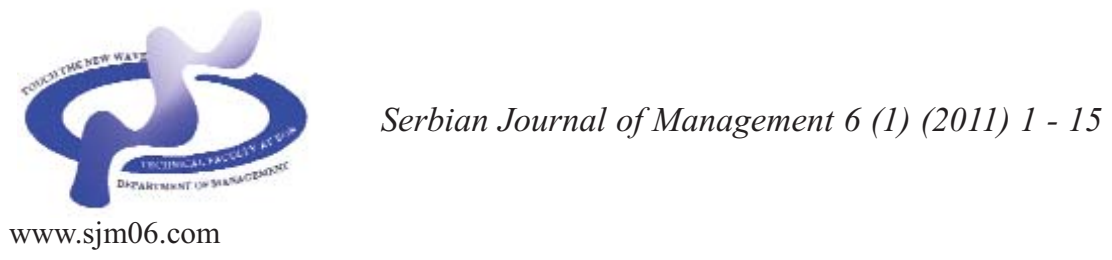

Serbian

Journal

\title{
EMPLOYEE INVOLVEMENT IN DECISION MAKING AND FIRMS PERFORMANCE IN THE MANUFACTURING SECTOR IN NIGERIA
}

\author{
Owolabi Lateef Kuye ${ }^{\mathrm{a} *}$ and Abdul-Hameed Adeola Sulaimon ${ }^{\mathrm{b}}$ \\ ${ }^{a}$ Department of Business Administration, University of Lagos, Nigeria

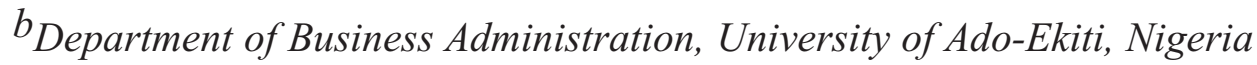

\begin{abstract}
This study examines the relationship between employee involvement in decision making and firms' performance in the manufacturing sector in Nigeria. Data were generated by means of questionnaires to 670 manufacturing firms on employee involvement in decision making and performance variables. Responses from the survey were statistically analysed using descriptive statistics, product moment correlation, regression analysis and Z-test (approximated with the independent samples t-test). The results of the study indicate a statistically significant relationship between employee involvement in decision making and firms' performance as well as reveal a significant difference between the performance of firms whose employee involvement in decision making are deep and the performance of firms whose employee involvement in decision making are shallow. The findings also reveal the involvement of participating firms in employee involvement in decision making. The implications of this study include the need for manufacturing firms to demonstrate high level of commitment to employee involvement in decision making for performance enhancement.
\end{abstract}

Keywords: employee involvement in decision making, firms' performance, manufacturing sector, culture, Nigeria.

\section{INTRODUCTION}

The manufacturing sector in Nigeria has been a focal subsector; but little is probably known about the influence of its employee involvement in decision making on firms' performance.

\footnotetext{
*Corresponding author:labikuye@yahoo.com
}

The particular attention in manufacturing emanates from the conviction that the sector is a potential instrument of modernisation, a creator of jobs, and a generator of positive spill-over effects (Tybout, 2000). Moreover, the growth in manufacturing output has been a key element in the successful 
transformation of most economies that have seen sustained rises in their per capita income (Soderbom and Teal, 2002). Focus should therefore be on manufacturing and those factors that may foster its growth. Thus, the justification for this study on manufacturing firms in Nigeria.

A modern forward-looking business does not keep its employees in the dark about vital decisions affecting them. It trusts them and involves them in decision making at all levels. "Command and control" is no longer an adequate model. A more open and collaborative framework will exploit the talents of all employees (Hewitt, 2002). Employees must be involved if they are to understand the need for creativity and if they are to be committed to changing their behaviour at work, in new and improved ways (Singh, 2009; Kingir and Mesci, 2010). Employee involvement in decision making serves to create a sense of belonging among the workers as well as a congenial environment in which both the management and the workers voluntarily contribute to healthy industrial relations (Noah, 2008).

In order to increase the workers commitment and humanise the workplace with the intention of improving work performance and good citizenship behaviour, managers need to permit a high degree of employee involvement (Cohen et al., 1997). Thus, the involvement of workers in decision making is considered as a tool for inducing motivation in the workers leading to positive work attitude and high productivity (Noah, 2009). However, researchers may be sceptical about the value and relevance of employee involvement in decision making to firm performance. It is in view of this that the study examines the following:
1. Whether there is a significant relationship between employee involvement in decision making and firms' performance.

2. Whether employee involvement in decision making has a significant impact on firms' performance.

3. Whether there is a significant difference between the performance of firms whose employees' involvement in decision making are (deep) high and the performance of firms whose employees' involvement in decision making are (shallow) low.

\section{DELIMITATION OF THE STUDY}

This study examines the relationship between employee involvement in decision making and firms' performance in the manufacturing sector in Nigeria. The choice of manufacturing sector was made because of its relevance and potential to Nigeria's economic development. Companies included in the sample were drawn from manufacturing firms in Lagos state. Lagos state was the focus because it is undoubtedly the commercial nerve-centre of Nigeria, with the largest concentration of industries (Iwugo et al., 2003), and over 55 percent of manufacturing firms in Nigeria have their head offices located in Lagos state (MAN, 1994; MAN, 2003; MAN, 2006). Therefore, Lagos offers an attractive place for the research.

\section{LITERATURE REVIEW}

Employee involvement in decision making, sometimes referred to as participative decision-making (PDM) is concerned with shared decision making in the work situation (Mitchell, 1973). Locke 
and Schweiger (1979) define it as 'joint decision making' between managers and subordinates. According to Noah (2008), it is a special form of delegation in which the subordinate gain greater control, greater freedom of choice with respect to bridging the communication gap between the management and the workers. It refers to the degree of employee's involvement in a firm's strategic planning activities. A firm can have a high or low degree of employee involvement. A high degree of involvement (deep employee involvement in decision making) means that all categories of employees are involved in the planning process. Conversely, a low degree of involvement (shallow employee involvement in decision making) indicates a fairly exclusive planning process (Barringer \& Bleudorn, 1999) which involves the top management only. A deep employee involvement in decision making allows the influence of the frontline employees in the planning process. These are the people who are closest to the customer and who can facilitate new product and service recognition, a central element in the entrepreneurial process (Li et al., 2006). This means that employee participation in the planning process surrounding the potential innovations may facilitate opportunity recognition throughout the organisation (Kemelgor, 2002; Zivkovic et al., 2009).

The attitudes that organisational results come from the top, that effective cultures are derived from the upper echelon, often tend to ignore the power and the contributions of those at lower levels (Woodworth, 1986). Thus ignoring the importance of employee involvement in decision making.

\section{EMPLOYEE INVOLVEMENT IN DECISION MAKING AND CULTURE}

However, one cannot write meaningfully about employee involvement in decision making or PDM without embedding it within a national cultural context (Hofstede, 2001). Thus, Sagie and Aycan, (2003) propose a framework that links various types of PDM to the cultural context. This framework was based on two dimensions of Hofstede: power distance and individualism-collectivism (I/C), as their link with PDM is strongest compared to other cultural dimensions (Heller et al., 1998).

Power distance signifies how individuals regard power differentials within the society or firms (Menzel et al., 2006). It influences the degree to which participation is practiced. In high power distance culture, decision-making is perceived as a privilege of management, and participation is considered as an infringement to management prerogative. Hence, employees are not involved in decision-making. In contrast, in low power distance culture, everyone is perceived to have the potential to contribute to the decision-making process; in fact, everyone is assumed to have equal rights. As such, employees consider it their right to participate in decisions that concern them (Sagie \& Aycan, 2003).

On the other hand, individualismcollectivism helps identifying the person or group involved in making decisions. The individualism-collectivism continuum is the extent to which an individual defines himself as either an independent agent or a part of the collective. Cultures high on individualism (or low in collectivism) emphasize the welfare, interests, and goals of the individual and his family. Each member in an individualistic culture is responsible for his 
actions. One's participation in decisionmaking is not the business of everyone else. Conversely, cultures high on collectivism (or low in individualism) emphasize the group. In collectivistic cultures the entire group may be held responsible for the actions of its individual members. Hence, no individual is allowed to make decisions alone without the approval of the entire group (Sagie \& Aycan, 2003).

According to Sagie and Aycan (2003), the combination of the two-by-two power distance (low/medium versus high) and individualism (low/medium versus high) give rise to four approaches to PDM: face-toface, collective, pseudo, and paternalistic participation (see Table 1).

Face-to-face PDM: The combination of high individualism and low power distance gives way to face-to-face interaction. Faceto-face PDM is a direct superior-subordinate interaction; thus, the employees rather than their representatives are involved in decision- making process. However, employees who are necessarily involved are those who possess the needed knowledge and information not possessed by the superior. In other words, managers provide opportunities for participation on the basis of one's merits (Witte, 1980; Sagie \& Aycan, 2003).

Table 1. Cultural dimensions and approaches to employee participation in decision making

\begin{tabular}{|llll|}
\hline & & \multicolumn{2}{l|}{ Individualism } \\
\cline { 3 - 4 } Cultural dimensions & & Low/Medium & High \\
\hline Power distance & Low/Medium & Collective PDM & Face-to-face PDM \\
& & & \\
& High & Parternalistic PDM & Pseudo-PDM \\
& & & \\
\hline
\end{tabular}

Adapted from Sagie \& Aycan (2003)
Collective PDM: Low or medium individualism in combination with low or medium power distance gives rise to collective PDM. It signifies an indirect involvement of employees in the decisionmaking process through consultative committees, work councils, or even the trade unions. Thus, it is an institutionalised involvement of workers in decisions that are relevant to labour-management relations (Sagie \& Aycan, 2003).

Paternalistic PDM: It emphasises high power distance and low individualism. The paternalistic approach represents the relationship between a superior and his subordinate which is likened to the relationship between a father and child. The (superior) father figure' is assumed to know what is best for the subordinate. He is trusted and expected to make the right decisions, which would be to the benefit of the subordinates. The subordinates believe that the superior acts as their representative by taking their well-being and protection into consideration in the decision-making process. This implies that employees rarely take part in the work decisions. If they do, participation is typically restricted to senior employees (Lam, 1986; Sagie \& Aycan, 2003).

Pseudo-PDM: Pseudo-PDM develops in a high individualistic and high power culture. This form of participation implies a directive management covered with a mask of participation. Directive managers pretending to be participative cannot earn the employees' trust; rather, organisation members are fully conscious of the disparity between the official democracy and actual dictatorship (Sagie \& Aycan, 2003). 


\section{BENEFITS OF EMPLOYEE INVOLVEMENT IN DECISION MAKING}

There is an assumption held by many scholars and managers that if employees are adequately informed about matters concerning them and are afforded the opportunity to make decisions relevant to their work, then there will be benefits for both the organisation and the individual (Shadur et al., 1999). Hence, the following are the benefits of employee involvement in decision making:

1. It increases employee's morale or job satisfaction and enhances productive efficiency (Chang \& Lorenzi, 1983).

2. It provides employees the opportunity to use their private information, which can lead to better decisions for the organisation (Williamson, 2008).

3. As a result of the incorporation of the ideas and information from employees, organisational flexibility, product quality, and productivity may improve (Preuss \& Lautsch, 2002).

4. It contributes to greater trust and a sense of control on the part of the employees (Chang \& Lorenzi, 1983).

5. Through employee involvement, resources required to monitor employee compliance (e,g., supervision and work rules) can be minimized, hence reducing costs (Arthur, 1994; Spreitzer \& Mishra, 1999).

6. When employees are given the opportunities of contributing their ideas and suggestions in decision making, increased firms' performance may result since deep employee involvement in decision making maximizes viewpoints and a diversity of perspectives (Kemelgor, 2002).
On his part, Sashkin (1976) identifies four corresponding outcomes of employees' involvement or participation in decision making:

1. Quality Improvement. Better information flow- and use- can clarify tasks goals, and bring about qualitatively better decisions.

2. Increase in employees' commitment and acceptance of decisions through a sense of "ownership" (having been involved in decision-making). This outcome increases the likelihood that goals will be effectively implemented.

3. Support of the participative approach and continuance of its effects overtime, due to learning through behavioural practice; this represents the behavioural process effect.

4. Increase adaptive capacity of the organisation. Development of shared norms and values may result into more effective use of inter-dependency relations among organisation members, through an organisational process based on collaboration, as opposed to win-lose conflict.

However, any potential benefits from greater employee involvement in decision making require that employee interest be aligned with firm's interests (Ogden, 1992; Spreitzer \& Mishra,1999). Individual contingency factors which support or hinder participative decision-making have also been identified by Sashkin (1976):

1. Participative decision-making is appropriate when sets of choices are clear, individuals show desire for greater desire for job involvements, and several individuals can be given similar choice sets (that is, effort in developing choices does not render such a plan economically impractical) this would always be true when technology is low. 
2. Participative decision-making may be useful in developing greater individual job responsibility.

3. Participative approach to decisionmaking is inappropriate when choices are complex, difficult to define, and vary in no small way; when task interdependence is very high; when environmental change is rapid.

\section{RELATIONSHIP BETWEEN EMPLOYEE INVOLVEMENT IN DECISION MAKING AND FIRMS' PERFORMANCE}

There is growing evidence that firm performance rests increasingly on the involvement of workers in decision making (Arthur, 1994; Daft \& Lewin, 1993; Deninson \& Mishra, 1995; Spreitzer \& Mishra, 1999). Scholars have argued that employee involvement contributes to organisational efficiency because it has the capacity to enhance the quality of decision making by increasing the inputs and promotes commitment to the outcomes of the decision making process in the workplace (Miller \& Monge, 1986; Markey, 1990, 2006). According to Spreitzer et al. (1997), workers who have greater choice concerning how to do their own work have been found to have high job satisfaction and consequently high performance. A significant relationship between frequency of employee's consultation and organisation commitment has also been established (Noah, 2008).

While employee involvement may reside at the core of many contemporary practices and research, the extent to which organisational-level performance gains are actually achieved through decentralising decision-making authority to lower level employee remains unclear (Richardson et al., 2002). Latham et al. (1994) contend that there is much less research evidence for the value of employee involvement on quality decision making. Scholars have also argued that employees' involvement in decision making may primarily serve to make them feel good about their jobs and organisations but do little to increase firm's performance (Wagner, 1994). Hence, the following hypotheses are proposed:

$H_{01}$ : There is no significant relationship between employee involvement in decision making and firms' performance.

$H_{02}$ : Employee involvement in decision making has no significant impact on firms' performance.

$H_{03}$ : There is no significant difference between the performance of firms whose employees' involvement in decision making are (deep) high and the performance of firms whose employees' involvement in decision making are (shallow) low.

\section{METHODOLOGY}

To investigate the relationships that exist between employee involvement in decision making and firms' performance in Nigeria, a cross-sectional survey design was employed by collecting data from a defined population. The use of survey research method is justified because it follows a correlational research strategy and helps in predicting behaviour (Bordens \& Abbott, 2002). It also helps to determine whether or not a relationship exists between the variables of study (Kerlinger, 1973). Responses were sought from manufacturing firms on a wide range of issues relating to employee involvement in decision making and firms' 
performance.

The population of this study comprised manufacturing firms in Nigeria. Since 55.2 percent of Nigeria's 2250 manufacturing firms are based in Lagos state (MAN, 1994, 2003), Lagos was therefore considered a good representation of manufacturing firms in Nigeria. Hence the population sample was taken from Lagos state.

The questionnaire was administered on manufacturing firms in Lagos state with the help of field research assistants. Manufacturing firms in Lagos state constitute the sample frame which is a representative subset of the population from which the sample was drawn. A top manager or chief executive of every selected firm was approached and persuaded to fill the questionnaire. These individuals were pleaded with to see the relevance of the study to their organisation. The manufacturing firms which did not participate were apathetic and unwilling to divulge information. Some adduced reasons such as management policy and suspicion to justify there lack of cooperation.

A simple random sampling technique was used in selecting the participating manufacturing firms. A total of 740 copies of the questionnaire were administered on the manufacturing firms but 670 were completed and returned. This represents 90.54 percent response rate. According to Saunders et al., (2003), sampling is a part of the entire population carefully selected to represent that population. The justification for using random sampling technique is that it eliminates the possibility that the sample is biased by the preference of the individual selecting the sample (Bordens \& Abbott, 2002). Another justification is that it is particularly necessary when one wants to apply research findings directly to a population (Mook, 1983).

The participating manufacturing firms constituted the units of analysis. The administration of the questionnaire was done on one top manager or chief executive at each firm surveyed. The use of primary data method is justified because according to (Cowton, 1998), it is the quickest and simplest of the tools to use, if publication is the aim.

\section{VARIABLES AND MEASURES}

\subsection{Employee involvement in decision making}

A five-point Likert scale of twenty items developed by Barringer and Bluedorn (1999) was employed. The scale which ranges from "no involvement to substantial involvement" was used to measure the degree to which employees from different hierarchical levels in a firm are involved in its (strategic planning process) decision making. The scores on the twenty items were summed up and averaged to determine the mean index of firms' employee involvement in decision making. An index of less than 4.0 was considered as low or shallow employee involvement in decision making while an index of 4.0 and above was considered as high or deep employee involvement in decision making. The variable had a reliability score of 0.90 which is quite high.

\subsection{Firms' performance}

Firms' performance scale includes ten performances criteria derived from Khandwalla (1995). The ten performance criteria include: profit growth, sales revenue, financial strength, operating efficiency, 
performance stability, public image, employee morale, environmental adaptation, new ideas, and social impact on the society. A five-point Likert scale was applied to measure the extent of the firms' performance, using the ten criteria. The scores on the ten items were summed up and averaged to determine the mean index of firms' performance. An index of less than 4.0 was regarded as low firms' performance while an index of 4.0 and above was regarded as high firms' performance. A reliability score of 0.86 was generated, indicating good reliability.

\section{ANALYTICAL TOOLS}

To derive useful meaning from the data, and examine the propositions of this study, data from the survey were analysed using SPSS (Statistical Package for Social Sciences) as well as the following descriptive and inferential statistical techniques:

Descriptive statistics such as mean, percentages and frequencies were employed in the study to measure demographic characteristics of respondents, to answer research questions relating to employee involvement in decision making and firms' performance. They are not meant to test a formal research hypothesis, but rather the summaries from a sample that characterise that sample (Simon, 2002). According to Kerlinger (1973), studying sets of numbers as they are is cumbersome; thus, it is necessary to reduce the sets in two ways: calculating the averages and calculating the measures of variability.

Product-moment correlation was used to examine the existence of relationship between employee involvement in decision making and firms' performance.

Regression Analysis was used to ascertain the amount of variations in the dependent variable which can be associated with changes in the value of an independent or predictor variable in the absence of other variables.

Z-test (approximated with the independent sample t-test in the SPSS package) was employed to test the hypothesised relationship as stated in null hypothesis 3 . Since the data were collected on a rating scale which is 'presumed to be interval scale', this parametric test is considered appropriate (Emory \& Cooper, 1991). Also, going by the central limit theorem, "for sufficiently large samples $(n=30)$, the sample mean will be distributed around the population mean approximately in a normal distribution. Even if the population is not normally distributed, the distribution of sample mean will be normal if there is a large enough set of samples" (Cooper \& Schindler, 2001). Since the sample size for this study is large $(n=670)$, the use of this statistic is justified.

\section{HYPOTHESES TESTS AND RESULTS}

The demographic profile of respondents in Table 2 reveals that majority of the respondents were males, constituting 86 percent of all the respondents. Respondents who were 30 but less than 60 years old make up 89.9 percent of the entire respondents. Those who were less than 30 years old constitute only 8.4 percent, while 60 years and above constitute an insignificant proportion (1.8 percent) of the entire respondents. Majority of the respondents sampled were married and they constitute 
Table 2. Demographic Profile of Respondents

\begin{tabular}{|l|l|r|r|}
\hline \multicolumn{5}{|c|}{ Sex } & Male & Frequency & \multicolumn{1}{c|}{ Percent } \\
\cline { 2 - 4 } & Female & 576 & 86.0 \\
\cline { 2 - 4 } & Total & 94 & 14.0 \\
\hline \multirow{5}{*}{ Age (in years) } & Less than 30 & 670 & 100.0 \\
\cline { 2 - 4 } & 30 but less than 40 & 56 & 8.4 \\
\cline { 2 - 4 } & 40 but less than 50 & 146 & 21.8 \\
\cline { 2 - 4 } & 50 but less than 60 & 200 & 29.9 \\
\cline { 2 - 4 } & 60 and above & 256 & 38.2 \\
\cline { 2 - 4 } & Total & 12 & 1.8 \\
\hline \multirow{5}{*}{ Marital status } & Single & 670 & 100.0 \\
\cline { 2 - 4 } & Married & 120 & 17.9 \\
\cline { 2 - 4 } & Divorced & 537 & 80.1 \\
\cline { 2 - 4 } & Widower & 5 & 0.7 \\
\cline { 2 - 4 } & Widow & 2 & 0.3 \\
\cline { 2 - 4 } & Total & 670 & 0.9 \\
\hline \multirow{5}{*}{ Educational qualification } & Bachelor's degree or equivalent & 217 & 32.4 \\
\cline { 2 - 4 } & Masters' degree & 308 & 46.0 \\
\cline { 2 - 4 } & Doctoral degree & 4 & 0.6 \\
\cline { 2 - 4 } & Professional qualification & 141 & 21.0 \\
\cline { 2 - 4 } & Total & 670 & 100.0 \\
\hline
\end{tabular}

80.1 percent, while 17.9 percent were single. percent. Doctoral degree holders constitute The divorced, widower and widow make up the least ( 0.6 percent) of all the educational only 1.9 percent. Also, in terms of qualifications.

educational qualification, majority (46 Table 3 shows the demographic profile of percent) of them were masters' degree firms. This reveals that the number of firms holders. Respondents who were holders of with workforce that is less than 50 bachelor's degree or equivalent constitute employees constitute the highest (17.9 32.4 percent while those who had percent), while those with above 350 professional qualifications make up 21 employees are the lowest (11 percent).

Table 3. Demographic Profile of Firms

\begin{tabular}{|l|l|r|r|}
\hline \multicolumn{2}{|c|}{} & Frequency & Percent \\
\hline \multirow{5}{*}{ Number of employees } & Fewer than 50 & 120 & 17.9 \\
\cline { 2 - 4 } & $50-100$ & 110 & 16.4 \\
\cline { 2 - 4 } & $101-150$ & 102 & 15.2 \\
\cline { 2 - 4 } & $151-200$ & 98 & 14.6 \\
\cline { 2 - 4 } & $201-250$ & 89 & 13.3 \\
\cline { 2 - 4 } & $251-350$ & 77 & 11.5 \\
\cline { 2 - 4 } & Above 350 & 74 & 11.0 \\
\cline { 2 - 4 } \multirow{4}{*}{\begin{tabular}{l} 
Age of organ \\
\cline { 2 - 4 }
\end{tabular}} & Total & 670 & 100.0 \\
\hline & Less than 5 & 16 & 2.4 \\
\cline { 2 - 4 } & 5 but less than 20 & 198 & 29.6 \\
\cline { 2 - 4 } & 20 but less than 30 & 206 & 30.7 \\
\cline { 2 - 4 } & 30 years and above & 250 & 37.3 \\
\cline { 2 - 4 } & Total & 670 & 100.0 \\
\hline
\end{tabular}


In terms of the age of the firms, those who are 30 years and above constitute the highest (37.3 percent). Organisations that are less than 5 years old constitute only 2.4 percent of the entire participating firms.

10.1. Mean indices, Correlation Coefficient, Regression analysis and Independent Samples Test

With respect to employee involvement in decision making, the mean index of participating firms was 3.81. The mean index of participating firms concerning firms' performance was 4.07.

Hypothesis $\left(\mathrm{H}_{01}\right)$ was tested through correlations coefficients test. Pearson's product moment correlations coefficient (0.733) indicates that employee involvement in decision making and firms' performance are significantly and positively correlated with each other at 0.01 level of significance. Therefore, the null hypothesis of no significant relationship is rejected. Thus, there is a significant relationship between employee involvement in decision making and firms' performance.

Hypothesis $\left(\mathrm{H}_{02}\right)$ was tested through a Regression Analysis. The results of the Regression Analysis of the relationship between employee involvement in decision making and firms' performance are shown in

Table 4. Regression Analysis of employee involvement in decision making and Firms' Performance a) Model Summary

\begin{tabular}{|l|c|c|c|c|}
\hline Model & $\mathrm{R}$ & R Square & Adjusted R Square & Std. Error of the Estimate \\
\hline & .733 & .537 & .536 & 4.839 \\
\hline
\end{tabular}

b) $A N O V A$

\begin{tabular}{|l|l|r|r|r|r|r|}
\hline Model & & Sum of Squares & & Mean Square & \multicolumn{1}{c|}{ F } & Sig. \\
\hline & Regression & 18146.848 & 1 & 18146.848 & 775.094 & .000 \\
\hline & Residual & 15639.516 & 668 & 23.412 & & \\
\hline & Total & 33786.364 & 669 & & & \\
\hline
\end{tabular}

c) Coefficients

\begin{tabular}{|c|c|c|c|c|c|c|}
\hline Model & & \multicolumn{2}{|c|}{ Unstandardized Coefficients } & $\begin{array}{c}\text { Standardized } \\
\text { Coefficients }\end{array}$ & & Sig. \\
\hline & (Constant) & 7.194 & 1.219 & & 5.903 & .000 \\
\hline & $\begin{array}{l}\text { EMPLOYEE } \\
\text { INVOLVEMENT } \\
\text { IN DECISION } \\
\text { MAKING }\end{array}$ & .440 & .016 & .733 & 27.841 & .000 \\
\hline
\end{tabular}

Dependent Variable: Firms' performance

$\mathrm{p}<0.05$ 
Table 4. Table $4 \mathrm{~b}$, shows that the analysis of variance of the fitted regression equation is significant with $\mathrm{F}$ value of 775.094 . This is an indication that the model is a good one. Since the p-value is less than 0.05 , it shows a statistically significant relationship between the variables at 95 percent confidence level. Therefore, the null hypothesis of no significant impact is rejected. Thus, employee involvement in decision making has a significant impact on firms' performance.

The $\mathrm{R}^{2}$ statistic in Table $4 \mathrm{a}$ indicates that the model as fitted explains 53.7 percent of the total variability in firms' performance. In other words, 53.7 percent of the total variability in firms' performance can be explained by employee involvement in decision making. The value of $\mathrm{R}^{2}=0.537$ shows that employee involvement in decision making is a good predictor of firms' performance.
The standardized coefficients (Beta) value in Table 4c reveals that the independent variable is statistically significant at 0.05 significant level.

Hypothesis $\left(\mathrm{H}_{03}\right)$ was tested using Independent Samples Test. The results of the independent sample t-test as revealed in Table 5a show that performance mean index (4.47) of firms with high employee involvement in decision making is different from the performance mean index (3.78) of firms with low employee involvement in decision making $\mathrm{y}$. This difference between the two mean was found to be statistically significant at $p<.05$ (Table $5 \mathrm{~b}$ ). Therefore, the null hypothesis of no significant difference is rejected. Thus, there is a significant difference between the performances of firms whose employee involvement in decision making are high and the performance of firms whose employee involvement in decision making are low.

Table 5. Independent Samples Test on Performance of Firms that have high employees involvement in decision making and those that have low employee involvement in decision making

a) Group Statistics

\begin{tabular}{|l|c|r|r|r|r|}
\hline & $\begin{array}{c}\text { EMPLOYEE } \\
\text { INVOLVEMENT IN } \\
\text { DECISION MAKING }\end{array}$ & $\mathrm{N}$ & Mean & \multicolumn{1}{c|}{$\begin{array}{c}\text { Std. } \\
\text { Deviation }\end{array}$} & Std. Error Mean \\
\cline { 2 - 6 } $\begin{array}{l}\text { FIRMS } \\
\text { PERFORMANCE } \\
\text { INDEX }\end{array}$ & LOW (Shallow) & 386 & 3.7803 & .77615 & 0.03951 \\
\cline { 2 - 6 } & HIGH (Deep) & 284 & 4.4690 & .31638 & 0.01877 \\
\hline
\end{tabular}

\section{b) Independent Samples Test}

\begin{tabular}{|l|c|c|r|r|r|r|}
\hline & \multicolumn{5}{|c|}{$\mathrm{t}$-test for Equality of Means } \\
\hline & $\mathrm{t}$ & $\mathrm{df}$ & \multicolumn{1}{c|}{$\begin{array}{c}\text { Sig. } \\
\text { (2-tailed) }\end{array}$} & $\begin{array}{c}\text { Mean } \\
\text { Difference }\end{array}$ & \multicolumn{2}{c|}{$\begin{array}{c}\text { I5\% Confidence } \\
\text { Interval of the } \\
\text { Difference }\end{array}$} \\
\cline { 5 - 8 } & & & & & Lower & Upper \\
\hline $\begin{array}{l}\text { FIRMS' } \\
\text { PERFORMANCE } \\
\text { INDEX }\end{array}$ & -14.113. & 668 & .000 & -.68870 & -0.78452 & -0.59289 \\
\hline
\end{tabular}




\section{1. CONCLUSIONS IMPLICATIONS FOR MANAGEMENT}

Manufacturing firms all over the world play vital roles in the growth and development of the economy. It is believed that the effectiveness and efficiency in performing these roles may inter-alia depend largely on employee involvement in decision making of the firms. However, the findings of the study reveal that on the average, the employee involvement in decision making of participating firms was low. This implies the possibility of managers of the firms not being critical about employee involvement in decision making, probably because of their practice of high power distance culture. In which case the employees are expected to be seen and not heared.

The findings of this study indicate a significant relationship between employee involvement in decision making and firms' performance. The results also reveal that firms with high employee involvement in decision making outperform firms with low employee involvement in decision making.

This study has some important implications for management of manufacturing firms. It signifies the need for manufacturing firms to exhibit high level of commitment to employee involvement in decision making in order to enhance their performance. In other words, an intensive employee involvement in decision making regime is a probable approach for increasing firm performance in competitive markets with uncertainty. This study can also help researchers to better understand the relationship between employee involvement in decision making and firms' performance in the Nigerian manufacturing sector. Thus, if the Nigerian manufacturing sector must grow and be competitive, its managers should encourage increased involvement in employee involvement in decision making activities.

\section{SUGGESTIONS FOR FURTHER STUDIES}

The following suggestions for future studies deserve some comments:

Future studies may need to expand to cover the service industry rather than limiting them to the manufacturing industry. Then, generalisation of the findings might be well justified.

Second, future study should also consider the analysis of firm size and firm age, and their influence on employee involvement in decision making. These might be relevant and imperative in making policy decisions for the firm..

Third, future research to investigate the influence of firms' performance on employee involvement in decision making might also be considered.

Finally, the sample was drawn from Lagos State, Nigeria. This limits the generalisations of the findings. Hence, the suggestion that future research should extend the study to manufacturing firms across the entire country. 


\title{
УТИЦАЈ УЧЕШЋА ЗАПОШЉЕНИХ У ДОНОШЕЊУ ОДЛУКА НА ПОКАЗАТЕЉЕ ПОСЛОВАЊА КОМПАНИЈЕ ПРОИЗВОДНОГ СЕКТОРА НИГЕРИЈЕ
}

\author{
Owolabi Lateef Kuye ${ }^{\mathrm{a} *}$ and Abdul-Hameed Adeola Sulaimon ${ }^{b}$ \\ a Department of Business Administration, University of Lagos, Nigeria

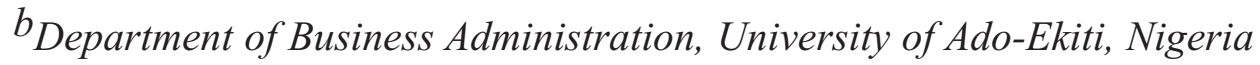

\begin{abstract}
Извод
У овој студији је показан однос између укључивања запошљених у доношење одлука и показатеља компаније у оквуру производног сектора Нигерије. Подаци су сакупљени коришћењем упитника укључујући 670 производних фирм, са питањима везаним за укључивање радника у процес доношења одлука. Одговори из упитника су статистички анализирани помоћу дескриптивне статистике, корелације момента производа, регресионе анализе и 3 теста (уз апроксимацију Т теста независне промењиве). Резултати студије индицирају статистички значајну везу између укључивања запошљених у доношењу одлука и перформанси компаније и потребу за тиме да производне фирме демонстрирају висок ниво посвећености циљу укључивања запослених у процес доношења одлука.
\end{abstract}

Кључне речи: укључивање запошљених у доношење одлука, перформансе компаније, производни сектор, култура, Нигерија.

\section{References}

Arthur, J.B. (1994) Effects of Human Resource Systems on Manufacturing Performance and Turnover. Academy of Management Journal, 37: 670-687.

Barringer, B.R., \& Bluedorn, A.C. (1999) The Relationship between Corporate Entrepreneurship and Strategic Management. Strategic Management Journal, 20: 421-444.

Bordens, S.K, \& Abbott, B.B. (2002). Research Design and Methods: A Process Approach (5th ed.) New York: McGraw-Hill.

Chang, G.S., \& Lorenzi, P. (1983) The Effects of Participative versus Assigned Goal Setting on Intrinsic Motivation. Journal of
Management, 9: 55-64.

Cohen, S., Chang, L, \& Ledford, G. (1997) A Hierarchical Construct of Selfmanagement Leadership and its Relationship to Quality of Work Life and Perceived Work Group Effectiveness. Personnel Psychology, 50: 275-308.

Cooper, D.R., \& Schindler, P.S. (2001). Business Research Methods (7th ed). New York: McGraw-Hill companies.

Cowton, C. J. (1998) The use of Secondary Data in Business Ethics Research. Journal of Business Ethics, 17: 423-434.

Daft, R.L., \& Lewin, A.Y. (1993) What are the Theories for the 'New' Organizational Forms? An Editorial Essay. Organizational Science, 4: 1-4. 
Denison, D.R. \& Mishra, A.K. (1995)

Toward a Theory of Organization Culture and Effectiveness. Organization Science, 6: 204-223.

Emory, C. W. \& Cooper, D.R. (1991). Business Research Methods (4th Ed.) Illinois: Richard D. Irwin Inc.

Heller, F.A.., Pusic, E., Strauss, G., \& Wilpert, B. (1998). Organizational Participation: Myth and Reality. New York: Oxford University Press.

Hewitt, P. (2002). High Performance Workplaces: The Role of Employee Involvement in a Modern Economy. www.berr.gov.uk/files/file26555.pdf

Iwugo, K. O., D’Arcy, \& Andoh, R. (2003). Aspects of Land-Based Pollution of an African Coastal Megacity of Lagos, Diffuse Pollution Conference, Dublin.

Kemelgor, B.H. (2002) A Comparative Analysis of Corporate Entrepreneurial Orientation between Selected Firms in the Netherlands and the U.S.A. Entrepreneurship and Regional Development, 14: 67-87.

Kerlinger, F.N. (1973). Foundations of Behavioural Research, New York: Holt, Rinehart and Winston, Inc.

Lam, M.N. (1986) Forms of Participation: A Comparison of Preferences between Chinese Americans and American Canadians. Canadian Journal of Administrative Science, 3: 81-98.

Khandwalla, R.N. (1995). The Management Style. New Delhi: McGrawHill Companies Inc.

Kingir, S., \& Mesci, M. (2010) Factors that affect Hotel Employees Motivation the case of Bodrum, Serbian Journal of Management, 5(1): 59 - 76.

Latham, G.P., Winters, D.C., \& Locke, E.A. (1994) Cognitive and Motivational Effects of Participation: A Mediator Study.
Journal of Organizational Behaviour, 15: 4964.

Li, L., Tse, C., \& Gu., B.Y. (2006) The Relationship between Strategic Planning and Entrepreneurial Business Orientation. The Chinese Economy, 39(6): 70-82.

Locke, E.A., \& Schweiger, D.M. (1979) Participation in Decision-making: One More Look. Research in Organizational Behaviour, 1: 265-339.

MAN (1994). Nigeria Industrial Directory. Manufacturing Association of Nigeria.

MAN (2003). Nigerian Business Directory: Under the Auspices of the Commonwealth Heads of Government Meeting. Manufacturing Association of Nigeria.

MAN (2006). Manufacturing Association of Nigeria. MAN Economic Review 20032006 (28).

Markey, R. (2006) The Internalisation of Representative Employee Participation and its Impact in the Asia Pacific. Asia Pacific Journal of Human Resources, 44(3): 342363.

Menzel, H.C., Krauss, R., Ulijn, J.M., \& Weggerman, M. (2006) Developing Characteristics of an Intrapreneurship Supportive Culture. Eindhoven Centre for Innovation Studies, the Netherlands Working Paper 06.10

Miller, K.L., \& Monge, P.R. (1986) Participation, Satisfaction, and Productivity: A Meta-analytical Review. Academy of Management Journal, 29(4): 727-753.

Mitchell TR. (1973) Motivation and participation: an integration. Academy of Management Journal, 16: 670-679.

Mook, D. G. (1983) In Defence of External Validity. American Psychologist, 38: 379-387.

Noah, Y. (2008) A Study of Worker 
Participation in Management Decision Making Within Selected Establishments in Lagos, Nigeria. Journal of Social Science, 17 (1): 31-39.

Ogden, S. (1992) The Limits of Employee Involvement: Profit Sharing and Disclosure of Information. Journal of Management Studies, 29: 229-248.

Preuss, G.A., \& Lautsch, (2002) The Effect of Formal versus Informal Job Security on Employee Involvement Programs. Industrial Relations, 57 (3): 517541.

Richardson, M.., Stewart, P., Danford, A., Tailby, S., \& Upchurch, M. (2004) 'Employeees' Experience of Workplace Partnership". Pp. 210-26 in M. Stuart \& M. M. Lucio (Eds.), Partnership and Modernization in Employee Relations. Basingstoke: Pagrave.

Sagie, A., \& Aycan, Z. (2003) A CrossCultural Analysis of Participative DecisionMaking in Organizations. Humam Relations, 56 (4): 453-473.

Sashkin, M. (1976) Changing toward participative management approaches: A model and methods. Academy of Management Review, July, 75-86.

Saunders, M., Lewis, P., \& Thornhill, A. (2003). Research Methods for Business students (3rd ed) England: Pitman Publishing.

Shadur, M.A., Kienzle, R., \& Rodwell, J.J. (1999) The Relationship between Organizational Climate and Employee Perceptions of Involvement: The Importance of support. Group and Organization Management, 24 (4); 479-503.

Simon, S. (2002) Descriptive Statistics, online version in www.childrensmercy.org www.people.ex.ac.uk

Singh, S.K.G. (2009) A Study on Employee Participation in Decision Making.
Unitar E-Journal, 5 (1): 20-38.

Soderbom, M., \& Teal, F. (2002). The Performance of Nigerian Manufacturing firms: Report on the Nigerian Manufacturing Enterprise Survey 2001. United Nations Industrial Development Organisation (UNIDO) and centre for the study of African economies, Department of Economics, University of Oxford. 1-73.

Spreitzer, G.M. Kizilos, M., \& Nason, S. (1997) A Dimensional Analysis of Empowerment in Relation to Performance, Job Satisfaction, and Job-related Strain. Journal of Management, 23 (5): 679-704.

Spreitzer, G.M., \& Mishra, A.K. (1999) Giving UP Control Without Losing Control: Effects on Managers' Involving Employees in Decision Making. Group and Organization Management, 24 (2): 155-187.

Tybout, J.R (2000) Manufacturing firms in developing countries; how well they do, and why? Journal of Economic Literature 38:11-44.

Wagner, J.A. (1994) Participation's Effects on Performance and Satisfaction: A Reconsideration of the Research Evidence. Academy of Management Review, 19: 312330.

Williamson, M.G. (2008) The Effects of Expanding Employee Decision Making on Contributions to Firm Value in an Informal Reward Environment. Contemporary Accounting Research, 25 (4): 1184-1209.

Witte, J.F. (1980) Democracy, Authority, and Alienation in Work: Workers' Participation in an American Corporation. Chicago: University of Chicago Press.

Woodworth, W.P. (1986) Managing From Below. Journal of Management, 12 (3): 391-402.

Zivkovic, Z., Mihajlovic, I., Prvulovic, S. (2009) Developing Motivational Model as a Strategy for HRM in Small Enterprises under Transitional Economy. Serbian Journal of Management, 4(1): 1-27. 